2012

\title{
Hearsay and the Confrontation Clause
}

Lynn McLain

University of Baltimore, lmclain@ubalt.edu

Follow this and additional works at: http://scholarworks.law.ubalt.edu/all_fac

Part of the Law Commons

\section{Recommended Citation}

Lynn McLain, Hearsay and the Confrontation Clause, (2012).

Available at: http://scholarworks.law.ubalt.edu/all_fac/893

This Article is brought to you for free and open access by the Faculty Scholarship at ScholarWorks@University of Baltimore School of Law. It has been accepted for inclusion in All Faculty Scholarship by an authorized administrator of ScholarWorks@University of Baltimore School of Law. For more information, please contact snolan@ubalt.edu. 


\section{Hearsay and the Confrontation Clause}

(C) 2012 Prof. Lynn McLain

University of Baltimore School of Law

(may be reproduced with attribution)

Overview: Only an out-of-court statement (OCS) offered for TOMA = hearsay (HS). The Confrontation Clause applies only to "testimonial” HS.

\section{Table of Contents}

Chart 1 FLOW CHART FOR HEARSAY AND CONFRONTATION

CLAUSE ANALYSIS...................................................

I. ADMISSIBILITY OR EXCLUSION UNDER THE RULES OF

EVIDENCE....................................................

II. THE EVIDENCE IS ADMISSIBLE UNDER THE EVIDENCE RULES! BUT DOES THE CONSTITUTION EXCLUDE IT? .............4

A. Confrontation Clause Overview.....................................4

B. If the Confrontation Clause Does Not Exclude the Evidence because the Hearsay is Nontestimonial, the Only Remaining Constitutional Safeguard Is the Due Process Clause.................................5

Chart 2 IS THE EVIDENCE AN “OUT OF COURT STATEMENT” (“OCS”)

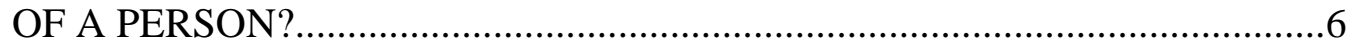

A. What is a "Statement"? ..........................................................................6

B. When is a Statement an "Out-of-Court" Statement?.....................................8

C. To Be Covered by the Hearsay Rule, a Statement Must Have Been Made by "a Person" .............................................9

Chart 3 IS THE OCS OFFERED FOR “TOMA”? .................................10

A. Hearsay Schemata ............................................... 10

B. TOMA Analysis ................................................... 10

C. Frequently Recurring Categories of Nonhearsay When an OCS is Relevant Short of Proving TOMA ...................................11

D. Evidence Offered for a Nonhearsay Purpose is Not Subject to the Confrontation Clause . .14 
I. HEARSAY IS TESTIMONIAL (AND THUS SUBJECT TO

THE RIGHT TO CONFRONT) IF IT IS:

A. U.S. Supreme Court Cases .............................................15

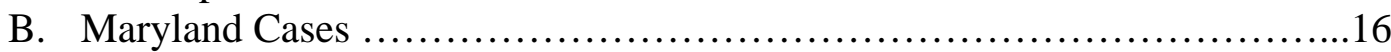

II. HEARSAY IS NONTESTIMONIAL (AND THUS NOT REACHED BY THE CONFRONTATION CLAUSE) IF IT IS: ......................18

A. U.S. Supreme Court Cases ...........................................18

B. Maryland Cases ..................................................... 19

Chart 5 DID THE ACCUSED “FORFEIT” HIS OR HER CONFRONTATION

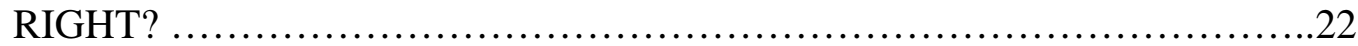

Chart 6 HEARSAY EXCEPTIONS AND RELATED ISSUES .....................23

A. OCS'S Within OCS's: Rule 5-805 ....................................23

B. Hearsay Exceptions that Are Applicable Only if the Declarant Testifies at Trial and is Subject to Cross-Examination: Rule 5-802.1 ...............23

C. Rule 5-803: Hearsay Exceptions Applicable Regardless Whether the Declarant is Available or Unavailable to Testify at Trial, and Regardless Whether the Declarant Testifies or Not........................25

D. Hearsay Exceptions Applicable Only When the Declarant is Shown, under Rule 5-804(b), to be Unavailable to Testify .........................31

E. Issues Related to Witness Intimidation ..................................32

F. Authentication of Internet and Cell Phone Evidence .........................33

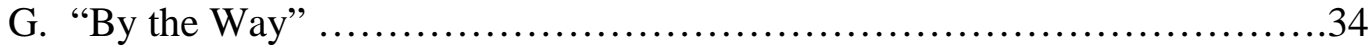




\section{Chart 1 FLOW CHART FOR HEARSAY AND CONFRONTATION}

\section{ADMISSIBILITY OR EXCLUSION UNDER THE RULES OF EVIDENCE}

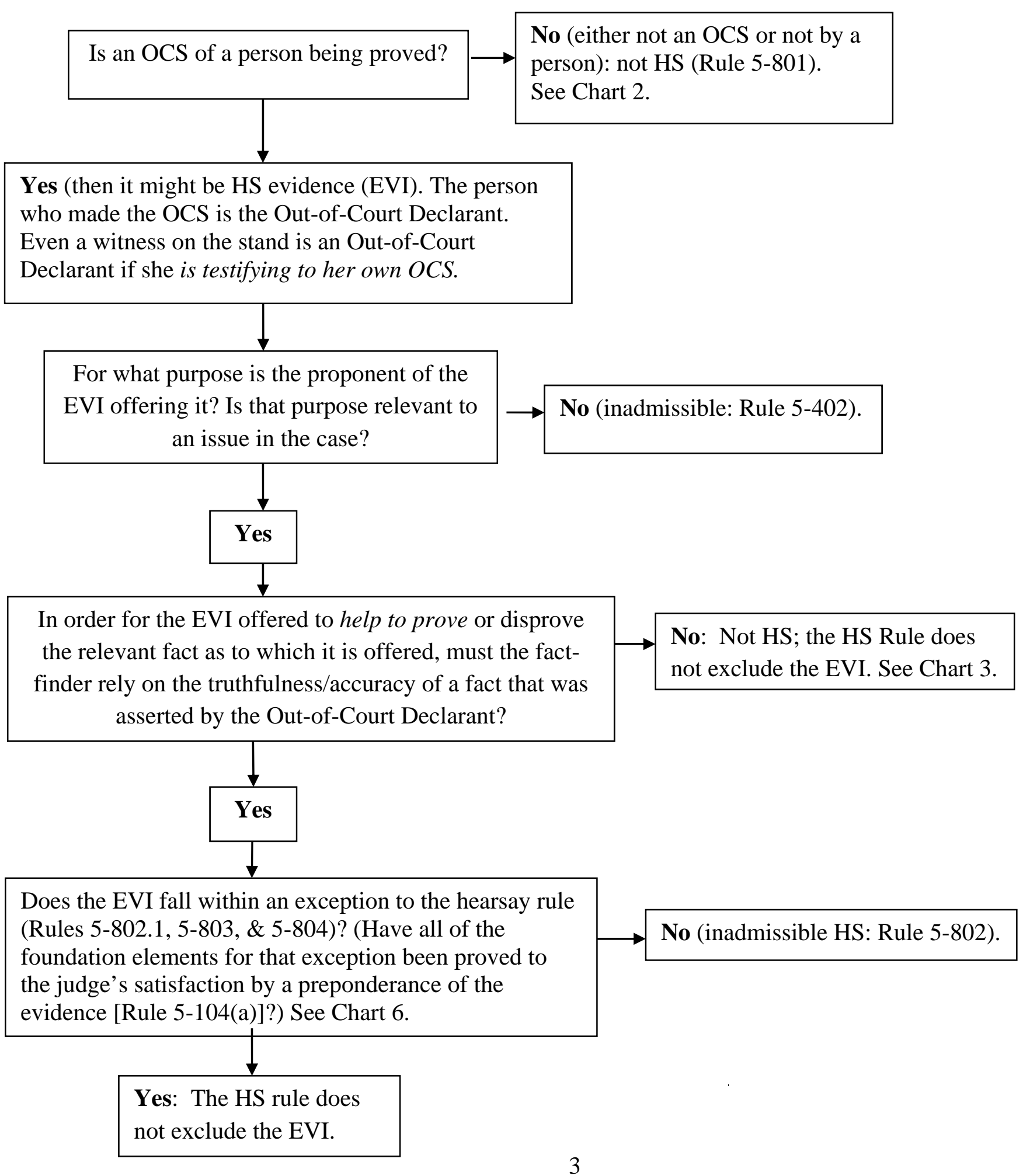




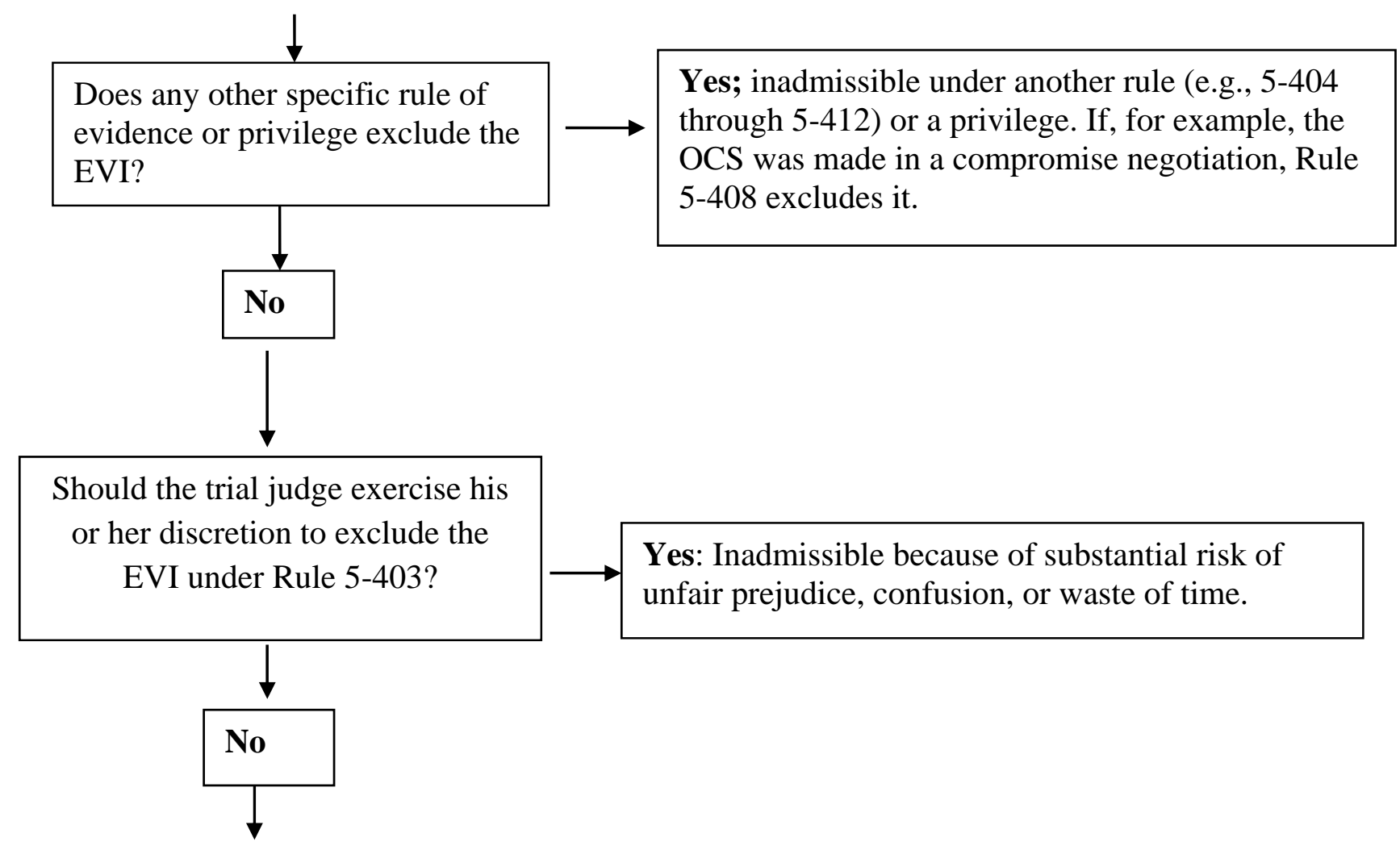

II. THE EVIDENCE IS ADMISSIBLE UNDER THE EVIDENCE RULES! BUT DOES THE CONSITITUTION EXCLUDE IT?

\section{A. Confrontation Clause Overview}

Is the EVI being offered (1) against a criminal accused AND

(2) at a trial on the merits?

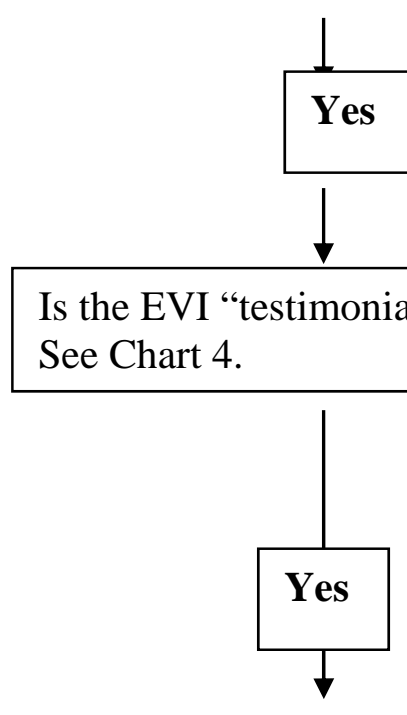

No: Confron. Cl. does not exclude it.

No: Confron. Cl. does not exclude it. Davis v. Washington, 554 U.S. 353 (2006).

UNLESS the EVI is based on the testimonial HS of a Declarant as to whom the defendant's confrontation right is not met. Derr v. State, 422 Md. 211 (2011).

PENDING CASE: Williams v. Illinois (U.S. No. 10-8505) raises this question for the content of DNA analysis by Cellmark of a vaginal swab from the victim, relied on under Fed. R. Evid. 703 and compared by the testifying expert to her own DNA analysis of the defendant's blood sample. (Illinois would distinguish Bullcoming.) 


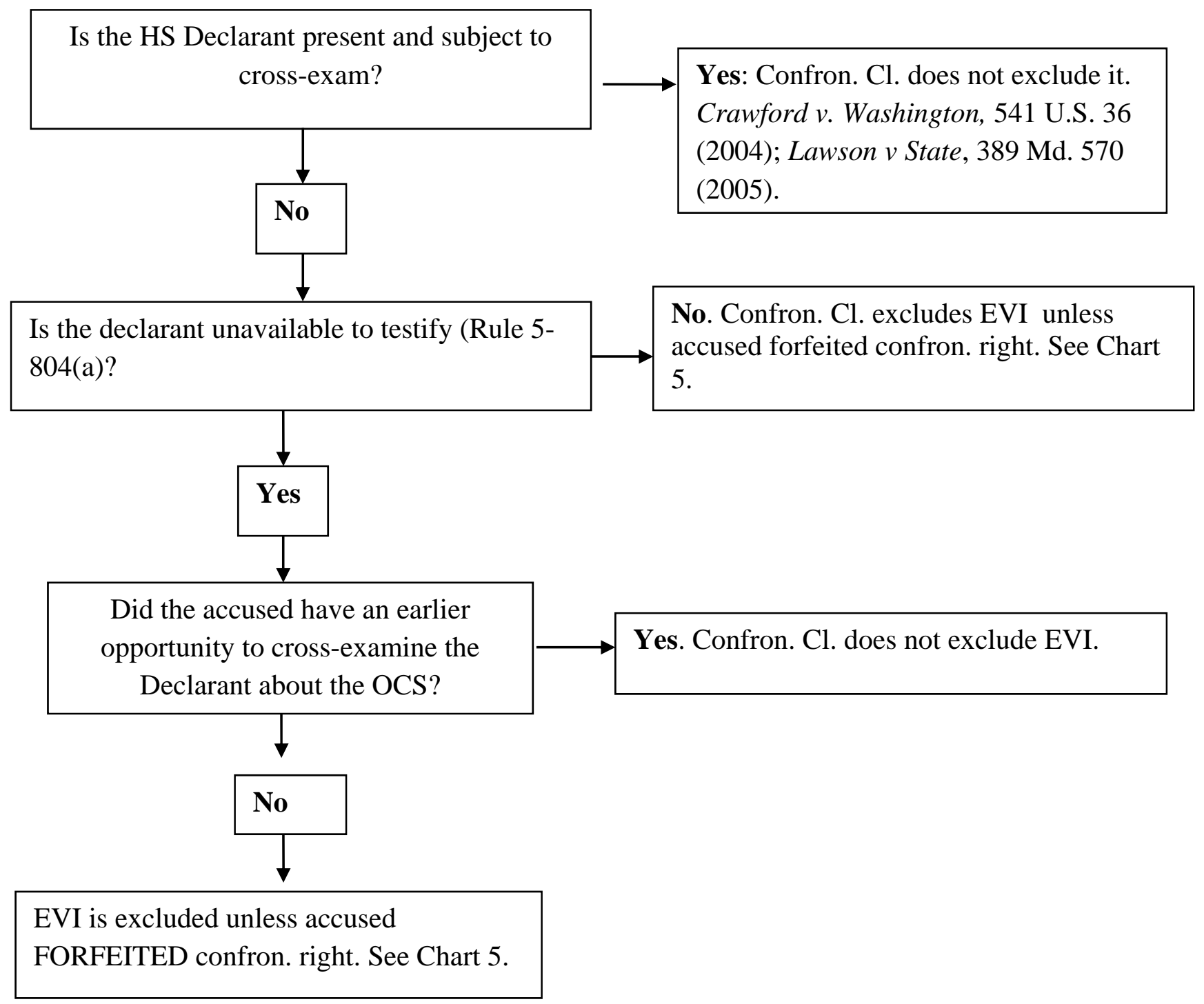

B. If the Confrontation Clause Does Not Exclude the Evidence because the Hearsay is Nontestimonial, the Only Remaining Constitutional Safeguard Is the Due Process Clause.

Due process requires that a verdict not be based on unreliable hearsay.

Lower appellate courts have therefore continued to apply Ohio v. Roberts, 448 US. 56 (1980) to evaluate the fact-finder's reliance on nontestimonial hearsay. Dictum in Michigan v. Bryant, 131 S. Ct. 1143 (U.S. 2011), supports this position.

Under Roberts, there is no error if the nontestimonial hearsay relied upon at trial either:

(1) Qualifies under a "firmly rooted" hearsay exception (probably all those listed in Title 5, except statements against penal interest, 5-804(b)(3)); or

(2) Is shown to have had equivalent "particularized guarantees of trustworthiness." 


\section{Chart 2 IS THE EVIDENCE AN “OUT OF COURT STATEMENT” (“OCS”) OF A PERSON?}

\section{A. What is a "Statement"?}

1. Rule 5-801(a) defines a "statement" as "(1) an oral or written assertion or (2) nonverbal conduct of a person, if it is intended by the person as an assertion."

"Statement" means an assertion of one or more facts or opinions. A statement may be either an oral assertion, a written assertion (e.g., note or document), or conduct intended as an assertion.

2. The statement is usually "verbal” (i.e., in words, no matter whether written or oral).

3. A "statement" also may be nonverbal assertive conduct" clearly intended as a substitute for particular words (nodding head to say yes or no, pointing to a person in a line-up, raising hand to indicate affirmative answer when asked, "who would like to ...?”).

4. "Statement does not include implied assertions from nonverbal nonassertive conduct (e.g., walking down the street, putting a coat on, raising an umbrella, even if offered to show that the person could walk, that it was cold out, or that it was raining).

5. "Statement" may, however, include an implied assertion from an utterance in words (if the utterance is offered to prove the truth of the assertion and has no independent relevance as circumstantial, nonhearsay evidence.

a. Stoddard v. State, 389 Md. 681 (2005) (Raker, J.) ("Is Erik going to get me?” was hearsay because relevant only if taken to mean “...like he got [killed] Calen?”).

b. Bernadyn v. State, 390 Md. 1 (2005) (Raker, J.) (hospital bill found in residence where defendant and illegal drugs were found was inadmissible hearsay when prosecutor argued in closing that hospital would want to be sure it had right address so it could be paid).

Judge Greene had held, while on the Court of Special Appeals, that the evidence was admissible nonhearsay. Judges Wilner and Battaglia, dissenting, agreed with Judge Greene.

The dissent would have followed those cases that hold that a name and address on a piece of mail are not intended by the writer "as an assertion," or "not intended to communicate the thought that the [named person] lived there," and thus do not constitute hearsay. Such evidence, rather, is properly admissible "as circumstantial evidence that [the defendant] stored his property, including his correspondence," in the place where it 
was found, which in turn tends to prove that the defendant exercises control over that place.

c. Fields v. State, 168 Md. App. 22 (2006) (D. Eyler, J.) (evidence that the name "Sat Dogg” was displayed on a screen at a bowling alley - the crime scene was properly admitted as nonassertive, circumstantial, nonhearsay evidence), aff'd on other grounds, 395 Md. 758 (2006) (Raker, J.).

d. In a 5 to 2 vote in Garner v. State, $414 \mathrm{Md} 372$ (2010)(Murphy, J.) the Court of Appeals held that the trial court had not erred in permitting a police officer to testify that he answered the cell phone confiscated from the defendant during his arrest, said "hello," and "a male voice” said, "Yo, can I get a 40.”

Judge Murphy, writing for the majority, reasoned that (1) "[w]hen a telephone is used to receive illegal wagers or to receive orders called in by persons who wish to purchase a controlled dangerous substance, the telephone becomes an instrumentality of the crime" and (2) "the rule against hearsay does not operate to exclude evidence of the 'verbal act' that established a consequential fact: Petitioner was in possession of a telephone called by a person who requested to purchase cocaine.”

The result of admissibility reached by this decision conformed to the results obtained for decades in the Court of Special Appeals and around the country as to similar evidence of telephone calls placing bets or requesting drugs. The "verbal act" rationale would differentiate the bookie-betting parlor and drug order cases like Garner from cases like Stoddard and Bernadyn. But Garner may indicate a partial retreat from the Stoddard majority’s approach.

The Garner majority could have affirmed under the facts there by looking at the evidence as nonassertive, circumstantial, nonhearsay evidence that a phone connected with the defendant received such a call, which was relevant even if the caller did not have any apparent intention to communicate, to the person who answered the phone, the fact that the defendant sold cocaine. This would be consistent with Judge Wilner's concurrence joined by Judges Greene and Battaglia in Stoddard.

If the Garner majority opinion is read as following this approach, then the evidence in Fields also was not hearsay; nor would the evidence in Bernadyn have been hearsay if offered for the proper, relevant, limited purpose that something with the defendant's name on it was found at the address where the drugs were found.

Interestingly, the Garner majority stated: "We need not either reaffirm or overrule either of those fact-specific cases in [Stoddard or Bernadyn] in order to hold that the rule against hearsay was not violated by Trooper Gussoni’s testimony about the telephone call at issue [in Garner].” Judges Battaglia and Greene were in the majority in Garner, and 
were joined by three judges who joined the court after Stoddard, Bernadyn, and Fields: Judges Adkins, Barbera, and Murphy. Chief Judge Bell and Judge Harrell, the only two remaining on the Court of Appeals who were in the majority in Stoddard, found themselves alone in the dissent in Garner.

e. Carpenter v. State, 196 Md. App. 212, 224-25 (2010) (Thieme, J.) (numbers shown on cell phone designating missed and received calls were not assertions or statements of a person; their relevance did not depend upon the belief or accuracy of the person(s) who made the calls, and the testimony of police detective to the numbers he saw was not hearsay).

f. In Fair v. State, 198 Md. App. 1 (2011) Kenney, J.), a paycheck with the defendant's name on it, with a pay date of the day before a police officer testified he found the paycheck in a car console with a handgun and underneath a bag of marijuana, was held to have been properly admitted by the trial court" "to show the Defendant's possessory interest in the vehicle'....”

Relying on Garner, as well as several federal cases (including a U.S. Supreme Court decision) holding that paychecks and money orders were not factual assertions, the Court of Special Appeals held that the paycheck was a nonhearsay verbal act, relevant and offered as "merely circumstantial nonassertive crime scene evidence."

The latter part of the rationale is more intellectually appealing here, because the fact that the paycheck bore the defendant's name and was found in the vehicle linked someone with that name to the vehicle, and it was offered for that limited purpose, rather than to show that the payor owed or had paid a certain sum. If it had been offered as to the latter purpose, and that fact had been relevant, it would have been relevant as a nonhearsay "verbal act."

\section{B. When is a Statement an "Out-of-Court" Statement?}

1. Rule 5-801(c) defines an out-of-court statement (“OCS”) as "a statement, other than one made by the declarant while testifying at the trial or hearing ...."

2. "Out-of-court" thus means that the evidence offered today at trial is of a statement made by any person somewhere else at another time. The other place may even have been another court proceeding.

\section{It is still "out-of-court" EVEN IF THE DECLARANT IS AT TRIAL} TESTIFYING TO HIS OR HER OWN EARLIER STATEMENT. (For hearsay exceptions requiring that the declarant also testify at trial, see Rule 5-802.1- certain prior inconsistent or consistent statements, prior identification of a person, prompt report of sexual assault, and past recollection recorded.) 
4. Why the preference for live testimony rather than out-of-court statements, even of a declarant who is now on the stand?
a. Better evaluation of demeanor evidence;
b. Better ability to cross-examine live memory; and
c. Out-of-court statement may not have been under oath.

\section{To Be Covered by the Hearsay Rule, a Statement Must Have Been Made by “a Person}

1. Rule 5-801 refers to "a person.” It does not include statements by animals such as a crowing rooster or a barking dog - or "statements" by machines, because neither can be cross-examined.

Foundation evidence regarding the training of the dog or the routine maintenance of the machines may be required, to show relevance and reliability.

\section{Numbers Shown on Cell Phone for Incoming Calls was Nonhearsay.}

Carpenter v. State, 196 Md. App. 212, 224-25 (2010) Thieme, J.) (numbers shown on cell phone designating missed and received calls were not assertions or statements of a person; their relevance did not depend upon the belief or accuracy of the person(s) who made the calls, and the testimony of the police detective to the numbers he saw was not hearsay).

\section{An Important Issue in the Confrontation Clause Context}

See, e.g., United States v. Washington, 498 F.3d 225 (4 $4^{\text {th }}$ Cir. 2007) (J. Niemeyer) (20 pages of data generated by Armed Forces Institute's Forensic Toxology Laboratory chromatograph machine and computers, showing that the defendant's blood sample contained ethanol and phencyclidine, were not hearsay, because the machine performing chromatography on the defendant's blood was not a "person" and could not be a “declarant” under Fed. R. Evid. 801), cert. denied (U.S. 2009); United States v. Moon, 512 F.3d 359, 361-62 ( $7^{\text {th }}$ Cir. 2008) (instruments' readings were not statements, though expert's conclusions based on them were), cert. denied (U.S. 2008).

The facts of Melendez-Diaz and Bullcoming did not directly raise this question, because there the evidence was not a machine printout but a certificate by a person, based on the machine readings. See also Derr v. State, Charts 1 and 4. 


\section{Chart 3 IS THE OCS OFFERED FOR “TOMA”?}

\section{A. Hearsay Schemata}

(1) EVI offered (determined to include an OCS OF A PERSON)
(2) MATERIAL FACT that EVI (1) is offered to help to prove
(3) Is the OCS offered for

TOMA?

1. If the evidence offered includes an "OCS" of a person, it is hearsay only if it is offered at trial to prove "TOMA."

2. TOMA = the truth of any fact that was being asserted by the declarant before the trial, at the time the declarant made the out-ofcourt statement.

B. TOMA Analysis

The OCS is offered for TOMA if the proponent is asking the jury to rely on something the declarant said in his/her OCS as true, accurate, correct.

The step-by-step analysis is:

1. Who was the out-of-court declarant?

2. What was the declarant asserting at the time he made the OCS?

3. For what purpose, to help to prove what relevant fact, is the proponent offering the evidence at trial?

4. How does the evidence tend to prove that fact?

Rule 5-401 relevance requires only the slightest probative value, not necessarily persuasive probative value.

5. If the evidence offered HELPS TO PROVE the fact as to which it is offered, even if the out-of-court declarant was either insincere or inaccurate, the evidence is NOT HEARSAY.

Ask, "Even if the assertions made in the OCS were incorrect, is it still relevant that the declarant made the statement?" If the answer to this question is yes, then the evidence is nonhearsay. 
The evidence may come in for the relevant nonhearsay purpose (subject to exclusion under Rule 5-403). A limiting instruction should be given upon request (Rule 5-105).

See Graves v. State, 334 Md. 30 (1994) (reversible error to admit arrestee's hearsay statement to police that defendant was his accomplice, for nonhearsay purpose of showing why police included defendant's picture in photographic array to be shown to victim: limited probative value for that purpose was substantially outweighed by danger of unfair prejudice).

Sanders v. State, 194 Md. App. 162, 179-87 (2010) (no abuse of discretion in excluding fact that defendant made a post-Miranda statement to police when offered by defense for nonhearsay purpose, as it "likely would have confused the jury and caused it to speculate why the statement was not introduced into evidence"), vacated on other grounds, 418 Md. 368 (2011).

\section{Frequently Recurring Categories of Nonhearsay When an OCS is Relevant Short of Proving TOMA}

1. Sometimes the mere fact that the OCS was made is relevant, regardless of whether the declarant was either sincere or accurate. In this event, a person testifying to the OCS can be fully cross-examined as to whether the OCS was made as s/he has testified.

a. Verbal acts (a/k/a "legally operative facts"): either the substantive law regarding the particular type of claim or defense requires that an outof-court statement have been made, e.g., defamation, contracts (including the offer and the acceptance), wills, or gives a particular legal effect to that type of statement (e.g., "Your money or your life!”).

These utterances are "magic words" under the substantive law; they take the speaker to a particular legal destination. See Garner v. State and Fair v. State, in Chart 2.

b. Statements offered to prove their effect on the hearer or reader, to prove that the hearer or reader was put on notice, or affecting the reasonableness of the hearer's or reader's subsequent conduct, e.g., "Be careful, the floor is wet," or, in a negligent hiring or retention case, what the employer had been told about the employee. 
i. $\quad$ Rehabilitation of an Impeached Witness by Evidence of Threats

Armstead v. State, 195 Md. App. 599 (2010)

(Kenney, J.), (no error in admitting State's witness's testimony that he was scared and that his life had been threatened, when witness was nervous and made inconsistent statements, and court had given limiting instructions that evidence was relevant only to witness's credibility and that there was no evidence that defendant was involved in or knew of the threats), cert. denied, $418 \mathrm{Md} .191$ (2011).

ii. $\quad$ Statements offered to prove why the police took certain actions are relevant for the effect on the hearer, but are usually excluded under Rule 5-403 when offered for this limited purpose, due to the risk that the jury will consider them for their truth.

Morris v. State, 418 Md. 194 (2011) (Harrell, J.)

reaffirms this general principle, but found no error under the facts there when the detective did not repeat the OCS, but testified that, based on the victim's, another officer's, and codefendant's statements, he retrieved certain items as associated with the alleged robbery.

\section{c. Statements that are offered as circumstantial evidence to prove only such matters as the declarant's being alive, conscious} (which may be relevant, e.g., to pain and suffering), able to speak a particular language, etc. at the time s/he made the OCS.

\section{d. Prior statements made by the declarant, that are offered only} to impeach or rehabilitate the declarant's credibility, but not as substantive evidence.

i. Prior inconsistent statements of the person who is sought to be impeached (Rules 5-613, witnesses, and 5-806, nontestifying hearsay declarants).

See Handy v. State, 201 Md. App. 521 (2011) (Sharer, J.) (defendant's OCS, recounting witness's OCS, was properly admitted: defendant's as an admission of a party opponent, 
and the OCS within it was admitted only to impeach witness with witness's own statement).

A party can impeach a witness or declarant with that witness's or declarant's own prior inconsistent statements. But a party cannot impeach one witness with someone else's out-of-court statement; to do that would be to offer the non-witness's statement for its truth, which is a hearsay purpose.

Sweetney v. State, 423 Md. 610 (2011) (Murphy, J.) (trial court properly precluded cross-examination of one police officer with out-of-court statement made by another officer in the same department, regarding search warrant "return" which did not list item that witness testified was found).

As to Rule 5-806, cf. Taylor v. State, 407 Md. 137 (2009) (impeachment of a key, non-testifying declarant -whose OCS has been admitted for its TOMA--by extrinsic evidence of a prior bad act under Rule 5-608(b) must be allowed, if it would be permitted if the declarant had testified at trial).

ii. Under certain circumstances the testimony of a witness or outof-court declarant may be rehabilitated by proof that that person's prior statements were consistent with his trial testimony. Rule 5-616(c)(2).

See Holmes v. State, 350 Md. 412 (1998) (Chasanow, J.) (use for this purpose may be permitted when substantive use under Rule 5-802.1(c) is not).

2. Statements that depend, for their relevance, on the declarant's having been sincere, but not on his/her having been factually accurate, are also not offered for TOMA. Here the OCS is offered for a nonhearsay purpose, as circumstantial evidence to prove the declarant's emotion, state of mind, knowledge, belief, intent, sanity, affection, ill will, etc., which is a relevant issue in the case.

See, e.g., Thomas v. State, 397 Md. 557, 575-80 (2007) (Raker, J.) (evidence of defendant's initial refusal to provide a blood sample was properly admitted as circumstantial evidence of consciousness 
of guilt, as State had laid proper foundation by showing that defendant was told blood was needed in reference to victim's health); Holland v. State, 122 Md. App. 532 (1998) (C. Moylan, J.).

Example: In A's trial for murder of B, the State offers, as relevant to A's motive or intent, C's testimony that A said to $\mathrm{C}$ a week before the murder, "B is a mean, nasty, rotten so-and-so."

How is this evidence relevant to the State's case? Is it relevant only if A was correct as to the facts A asserted, i.e., that B was really mean, nasty, etc?

No. It will be probative simply if the declarant $A$ believed that the fact he asserted was true: here, that B was nasty, etc., even if A is sadly mistaken about $\mathrm{B}$. The evidence may properly be admitted for a nonhearsay purpose, as circumstantial evidence that A disliked $\mathrm{B}$, which is relevant to A's motive and intent. The evidence would help to prove the fact it is offered at trial to prove, even if A was factually wrong, and B was really a kind and lovely person.

Now assume instead that the State calls C to testify to A's OCS one week before the murder, "I hate B." This OCS is a direct assertion by A of A's state of mind, and is offered to prove that A was accurate, i.e., did have the state of mind, i.e., A hated B. This OCS is offered to prove TOMA and is hearsay (but it will be admissible under the state of mind hearsay exception, Rule 5-803(b)(3)).

\section{Evidence Offered for a Nonhearsay Purpose is Not Subject to the Confrontation Clause}

Crawford v. Washington, 541 U.S. 36, 59 n.9 (2004) ("The Clause...does not bar the use of testimonial statements for purposes other than establishing the truth of the matter asserted."); Tennessee v. Street, 471 U.S. 409 (1985) (defendant's rights under the confrontation clause were not violated by the introduction of the confession of an accomplice for the nonhearsay purpose of rebutting respondent's testimony that his own confession was coercively derived from the accomplice's statement). 


\section{Chart 4 THE CONFRONTATION CLAUSE: IS THE HEARSAY “TESTIMONIAL?”}

Text of U.S. Constitution amend. VI: An accused has the right to confront "the witness" against him or her. In pari materia: Md. Decl. of Rights art. 21.

\section{HEARSAY IS TESTIMONIAL (AND THUS SUBJECT TO THE RIGHT TO CONFRONT) IF IT IS:}

\section{A. U.S. Supreme Court Cases}

(1) Ex parte testimony at a preliminary hearing; or

(2) A plea allocution; or

(3) Grand jury testimony; or

(4) Prior trial testimony; or

(5) “Statements taken by police officers in the course of interrogations...”

Crawford v. Washington, 541 U.S. 36 (2004).

In Crawford, the testimonial statements were made during a "structured, recorded" interrogation at the police station, when the declarant and her husband were suspected of having committed an assault.

Crawford focused on the historical context of the $6^{\text {th }}$ Amendment: antipathy toward “Bloody Mary's” government's gathering of formal solemn ex parte statements to be used in criminal prosecution.

(6) Police "interrogations solely directed at establishing the facts of a past crime, in order to identify (or provide evidence to convict), the perpetrator. The product of such interrogations, whether reduced to a writing signed by the declarant or embedded in the memory (and perhaps notes) of the interrogating officer, is testimonial."

Davis v. Washington, 554 U.S. 353 (2006).

Both an affidavit signed by DV victim and her oral statements to police at the marital home, where her husband, Mr. Hammon, was in another room, with another officer, were testimonial.

Davis's companion case, Hammon v. Indiana, 554 U.S. 353 (2006). (J. Thomas dissented as to Hammon facts.) 
The Davis/Hammon Court looked at the "primary motive" (viewed "objectively") of the police/police agent, in asking the particular questions: was it to resolve an ongoing emergency (yielding nontestimonial statements) or to help to prove past criminal conduct/agency "some time after the events described were over" (yielding testimonial statements)? and (2) the relative degree of solemnity and formality of the interrogation. Both of these factors were held to be relevant to what an objective declarant would take to be the primary purpose of his or her statements.

Dictum: "volunteered testimony" in absence of interrogation would still be testimonial.

(7) Notarized certificates by analysts of "a state laboratory required by law to conduct chemical analysis upon police request" that a seized substance was cocaine and how much it weighed.

Melendez-Diaz v. Massachusetts, 129 S. Ct. 2527 (2009) (5 to 4 decision: dissent by J. Kennedy, joined by C.J. Roberts, J.Breyer and J. Alito).

But dictum: "notice and demand" statutes are constitutional. Note: The State must provide notice, e.g., under Cts. \& Jud. Proc. § 10-1001 through 10-1003 of a state chemist's report regarding a controlled substance before each trial, including retrials, even where the defense had cross-examined the expert at the first trial. Harrod v. State, 423 Md. 24 (2011).

(8) In a case like \#7, the witness subject to cross must be either the person who performed or who witnessed the tests. (Here, the lab analyst who performed the tests, and certified and signed the blood alcohol concentration results, had been put on unpaid leave.)

Bullcoming v. New Mexico, 131 S.Ct. 2705 (U.S. 2011) (same 4 dissenters as in Melendez-Diaz) (J. Sotomayor concurred in part).

\section{B. Maryland Cases}

\section{$\underline{\text { Statements To or By Agents of Police }}$}

(9) Statements of 8 and 10-year-old children in an interview by a social worker working in tandem with and in presence of police officers, when child abuse had been reported and the children had already accused defendant to the police.

Snowden v. State, 385 Md. 641 (2005) (Harrell, J.) (adopting test of "whether the statements were made under circumstances that would lead an objective declarant reasonably to believe that the statements would be available for use later at trial"). 
(10) Nontestifying co-defendant's written and taped statements to police at the police station.

Codefendant had made a "miscellaneous agreement" functionally equivalent to a guilty plea agreement, that would become effective after defendant's jury trial (unless the codefendant made a successful motion for acquittal). Because the codefendant had waived his right to actively participate in the trial, the trial court should have treated his confession under Crawford, rather than simply under Bruton.

Morris v. State, 418 Md 194 (2011) (Harrell, J.).

(11) DV assault victim's excited statements to responding police, where defendant was known to be sitting on steps outside victim's apartment and there were no apparent severe injuries requiring immediate medical attention.

State v. Lucas, 407 Md. 307 (2009), (Adkins, J.).

(12) Brock v. State, __Md. App._n.5, 2012 WL 400439 (Feb. 9 2012) (D. Eyler, J.) (State conceded that statements declarant made to police in months following stabbings were testimonial).

Autopsy Reports [Is M.E. an Agent of Police?]

(13) “Opinions, speculation and other conclusions drawn [in autopsy reports] from the objective findings in autopsy reports” are testimonial.

Rollins v. State, 392 Md. 455 (2006) (Greene, J.). Accord Costley v. State, 175 Md. App. 90 (2007).

\section{$\underline{\text { Lab Results }}$}

(14) Derr v. State, 422 Md. 211 (2011) (Greene, J.) held, relying on Bullcoming, that the Confrontation Clause demands that either the analyst who performed DNA results or a supervisor who observed it must testify at trial.

It thus held inadmissible a testifying expert's testimony relying in part on the results of another's 2002 DNA analysis, when she had supervised only the subsequent "matching" 2004 DNA analysis. Derr applied the same reasoning to the results obtained by a serology examiner in 1985 regarding blood and semen at the time of the charged rape.

J. Harrell, joined by J. Battaglia, concurred as to the testimony based on the 2002 DNA analysis, but dissented as to the expert's testimony relying on the 1985 serological results, which they found to be merely "raw data" and different in several significant ways from the certificates in Melendez-Diaz and Bullcoming. 
Note that the Fourth Circuit held the opposite way to Derr in United States v. Summers, 666 F. 3d 192 (4 ${ }^{\text {th }}$ Cir. 2011), and that the U.S. Supreme Court has heard argument on this question in Williams $v$. Illinois.

\section{$\underline{\text { Statements to and by Medical Personnel }}$}

(15) Report prepared by SAFE nurse employed by the Sexual Assault Center at Prince George's Hospital, where victim had been taken by police officer (who requested certain tests) after victim had been examined and bandaged at another hospital; the $2^{\text {nd }}$ hospital performed forensic tests and prescribed antibiotics; report showed location of physical injuries observed by SAFE nurse.

Green v. State, 199 Md. App. 386 (2011). .J. Salmon, joined by Kehoe and Hotten, JJ., distinguished autopsy reports prepared by M.E.'s, 199 Md. App. 403-04, but also rejected the fact/opinion dichotomy created in Rollins.

\section{N.b. The Confrontation Clause will not exclude, even if testimonial HS:}

(1) The accused's own statement, or another's adopted by the accused (see Rule 5-803(a)(1)-(2)). Crawford; Cox v State, 421 Md. 630(2011) (Greene, J.); or

(2) Dying declarations (see Rule 5-804(b)(2)). Crawford n. 6.

\section{HEARSAY IS NONTESTIMONIAL (AND THUS NOT REACHED BY THE CONFRONTATION CLAUSE) IF IT IS:}

\section{A. U.S. Supreme Court Cases}

(1) Business records (generally) (see Rule 5-803(b)(6)); or

(2) “Casual remarks to an acquaintance” or overheard, off-the-cuff remarks; or

(3) Statements by a coconspirator during and in furtherance of a conspiracy (see Rule 5-803(a)(5)); or

(4) Statements made “unwittingly" to an informant or undercover officer.

Crawford v. Washington, 541 U.S. 36 (2004).

(5) 911 call where a declarant reasonably would conclude that operator, as agent of police, “objectively" had "primary purpose" "to enable police assistance to meet an ongoing emergency.” 
Davis v. Washington, 554 U.S. 353 (2006).

Declarant-victim's initial call in Davis was "plainly a call for help against a bona fide physical threat"; victim's responses were "frantic."

(6) Dictum in Melendez-Diaz v. Massachusetts, 129 S. Ct. 2527 (2009): Merely routine records kept in the ordinary course of business such as of routine maintenance of equipment. Eg., United States v. Cabrera-Beltran, 660 F.3d 742 ( $4^{\text {th }}$ Cir. 2011) (Treasury Enforcement Communications Systems records of vehicles crossing into the United States and their license plates).

(7) Dictum in Melendez-Diaz: Certificates of authentication of a pre-existing official document.

(8) Shooting victim's statements in response to police's questions, as victim lay mortally wounded, outside a gas station.

Michigan v. Bryant, 131 S.Ct.1143 (U.S. 2011) (over vehement dissent of J. Scalia and J. Ginsburg).

Majority opinion by J. Sotomayor held that whether statements are testimonial is determined by a multi-factor analysis, and the presence or absence of one factor is not dispositive.

The factors include: (1) whether there seemed to be an ongoing emergency; (2) the degree of formality of the interrogation; and (3) an objective evaluation of the questions posed and answers given under all the circumstances in which the declarant made the statements at issue.

As to factor (1), she noted that a deadly weapon had been used; the medical condition of the victim (who here asked several times when medical help would arrive), and that the "zone of potential victims” was broader than in a domestic violence case.

Seemingly veering away from Crawford's historical reasoning and back toward that of Ohio v. Roberts' focus on reliability, J. Sotomayor wrote: "implicit in Davis is the idea that because the prospect of fabrication in statements given for the primary purpose of resolving that emergency is presumed significantly diminished, the Confrontation Clause does not require such statements to be subject to the crucible of crossexamination.”

\section{B. Maryland Cases}

$\underline{\text { Statements to Police and Their Agents }}$

(9) Dying declaration by victim, under facts similar to those in Michigan v. Bryant: chaotic situation, and shooter's whereabouts were unknown. 
Head v. State, 171 Md. App. 642 (2006).

(10) DV victim's excited utterances, imploring defendant to stop, heard by 911 operator over cell phone that had been left on during the assault.

Marquardt v. State, 164 Md. App. 95 (2005) (Kenney, J.), cert. denied, 390 Md. 9 (2005).

(11) DV victim's sobbing utterances in two 911 calls, requesting police and an ambulance and describing defendant and his car (defendant hung up phone the first time; the second time victim says he has left but she knows he is coming back).

Clark v. State, 188 Md. App. 110 (2009) (Alpert, J.).

(12) 911 call reporting license tag numbers and color of car in which shooter had just fled after leaving carry-out where shooting occurred; caller noted that she was not summoning the police: they were already on the way).

Langley v. State, $421 \mathrm{Md} .560$ (2011) (4 to 3 decision) (Harrell, J.) (majority relied on Bryant; C.J. Bell and JJ. Greene and Eldridge dissented).

(13) Several excited utterances made by declarant while pacing back and forth, to responding police officer's questions; declarant had himself been stabbed, while trying to prevent flight of assailant who had fatally stabbed declarant's friend at a crowded tavern. When officer arrived, both victims were bleeding, and assailant's whereabouts were unknown. Officer called for medical assistance twice, and testified it took the police about 30 minutes to secure the tavern and make sure the suspect was not still there. Weapon was a knife. Not a domestic violence case.

"Viewed objectively, the total circumstances...make clear that 'the primary purpose' of the officer's questioning... was to meet an ongoing emergency.”

Brock v. State, __Md. App_, 2012 WL 400439 (Feb. 9, 2012) (D. Eyler, J.).

Statements to Medical Personnel

(14) Statements by injured child to nurse examining him when admitting him to pediatric ward, describing who had harmed him, even though child had been brought to emergency room by police, who were questioning defendant.

Griner v. State, 168 Md. App. 714 (2006) (Salmon, J.).

$\underline{\text { Casual Remarks }}$

(15) Casual remarks made by one inmate to another, describing the alleged crime. 
Cox v. State, $421 \mathrm{Md} .630$ (2011) (Greene, J.) (noting similarity of facts to those of Dutton v. Evans, 400 U.S. 74, (1970)). See id. at 650.

"We hold that when the State seeks to introduce an out-of-court statement against a criminal defendant, the proper inquiry under Crawford and Bryant is to determine whether a reasonable person in the declarant's situation would have made the statement 'with a primary purpose of creating an out-of-court substitute for trial testimony.' Bryant, 562 U.S. at _,131 S. Ct. at 1155.”

$\underline{\text { Parts of Autopsy Reports }}$

(16) "[R]outine, descriptive and not analytical, [but] objectively ascertained and generally reliable facts" in autopsy reports are nontestimonial; the recording of them is required by Md. Health Gen. §5-311.

Rollins v. State, 392 Md. 455 (2006).

This portion of Rollins is arguably implicitly overruled by Melendez-Diaz and Bullcoming. See Derr v. State, 422 Md. 211 (2011); Green v. State, 199 Md. App. 386 (2011). 


\section{Chart 5 DID THE ACCUSED “FORFEIT” HIS OR HER CONFRONTATION RIGHT?}

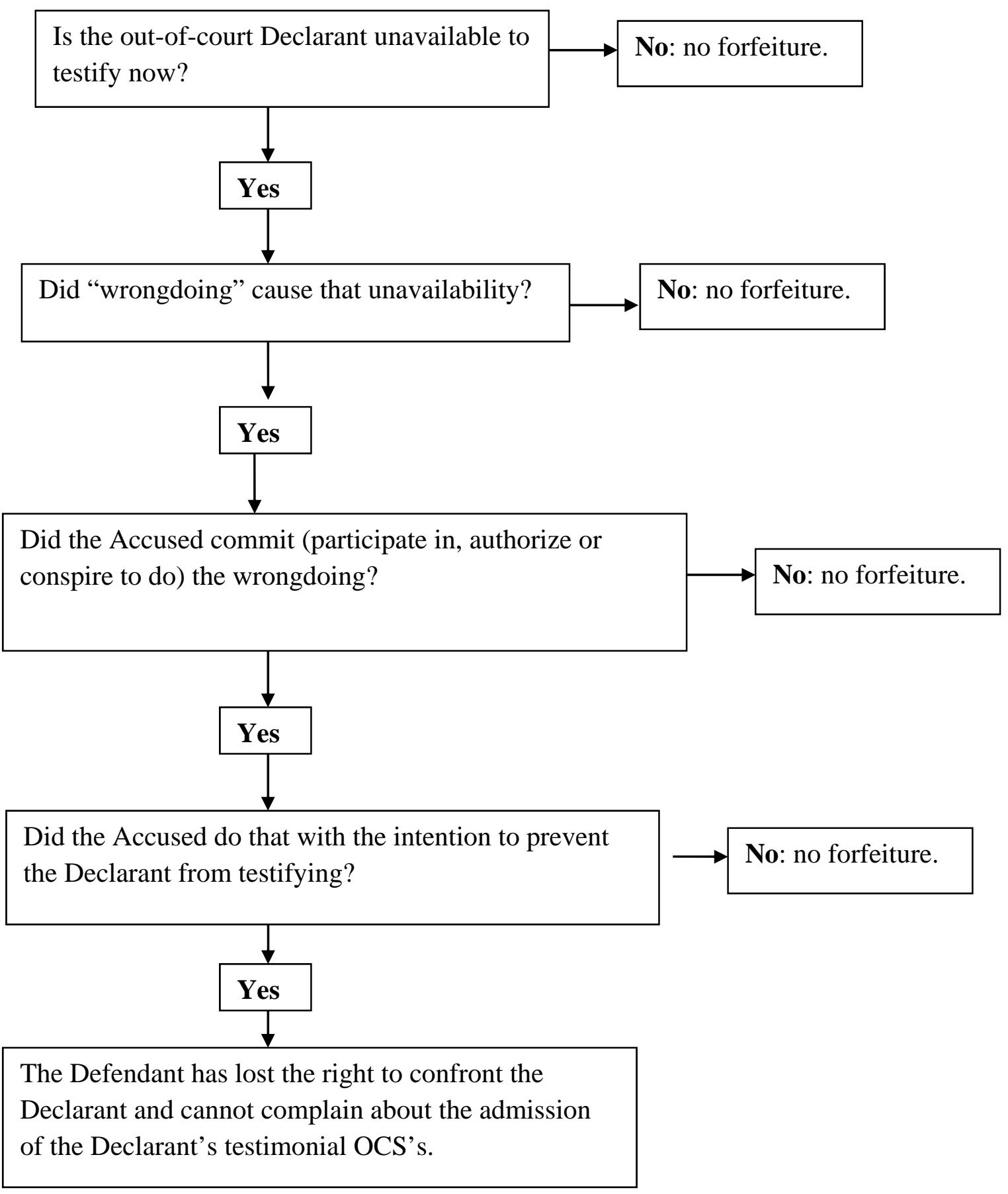

Authority: Giles v. California, 554 U.S. 353 (2008). N.b. not only dicta in majority opinion (Scalia) but also clearly the partial concurrence (Souter \& Ginsburg) and the dissent (Breyer, Stevens \& Kennedy) leave the door open for finding such intent upon proof of an intent to "isolate the victum and to stop her from reporting abuse to the authorities." 


\section{Chart 6 HEARSAY EXCEPTIONS AND RELATED ISSUES}

\section{A. OCS'S Within OCS's : Rule 5-805}

When evidence contains OCS's by more than one declarant, each OCS must be evaluated. If there is more than one "level" of evidence, i.e., we are asked to rely on one OCS to prove another OCS made earlier, then we can't get to the earlier OCS unless the more recent one is admissible (either as nonhearsay or hearsay falling within a hearsay exception). See Cooley v. State, 157 Md. App. 101 (2004) (one level of OCS was nonhearsay and the other was hearsay falling within an exception), rev'd on other grounds, 385 Md. 165 (2005); State v. Jones, 138 Md. App. 178 (2001) (Hollander, J.).

\section{B. Hearsay Exceptions that Are Applicable Only if the Declarant Testifies at Trial and is Subject to Cross-Examination: Rule 5-802.1}

N.b: The hearsay may be proved by the testimony of someone other than the declarant, as long as the prerequisites of the Rule are met.

\section{Rule 5-802.1(a): A subcategory of a testifying witness's prior inconsistent statements (“Nance statements").}

\section{The required foundation:}

a. The witness-declarant must testify at trial and be subject to cross-examination concerning the statement; and

b. If this requirement is met, then Rule 5-802.1(a) permits substantive use of a witness's prior inconsistent statements if they are either:

(1) written and signed; or

(2) stenographically or electronically recorded; or

(3) made under oath at deposition, trial, or in a hearing or another proceeding, including a grand jury proceeding.

E.g., Marlin v. State, 192 Md. App. 134, 144-47 (2010) (Hollander, J.)(recanting witness's prior inconsistent, audio recorded statement to police was properly admitted by J. Glynn), cert. denied, 415 Md. 339 (2011).

\section{Rule 5-802.1(b): A Subcategory of a Testifying Witness's Prior Consistent Statements}

The required foundation: 
a. Witness must testify at trial and be "subject to cross-examination concerning the statement";

b. Prior statement must be consistent with witness's testimony at trial;

c. Prior statement must be "offered to rebut an expressed or implied charge against the declarant of fabrication, or improper influence or motive;” and

d. Prior statement must precede the alleged improper influence or motive to be admissible as substantive evidence under Rule 5-802.1(b). Holmes v. State, 350 Md. 412, 712 A.2d 554 (1998) (Chasanow, J.); Thomas v. State, 202 Md. App. 386 (2011) (Raker, J.).

\section{Rule 5-802.1(c): The Witness's Prior Identification of a Person (at a Line-Up, etc.)}

E.g.,Marlin v. State, 192 Md. App. 134, 144-47 (2010) (Hollander, J.) (finding evidence of identification at photo array by recanting witness admissible), cert. denied, 415 Md. 339 (2011).

N.b.: Due process issue arises only if state action has made the circumstances unduly suggestive. Wood v. State, 196 Md. App. 146, 151- 63 (2010) (C. Moylan, J.), cert denied, 418 Md. 192 (2011). Accord Perry v. New Hampshire, 132 S.Ct. 716 (U.S. 2012).

\section{Rule 5-802.1(d): Prompt Report of Sexual Assault, Consistent with Declarant's Trial Testimony}

Required foundation:

a. Witness must testify at trial and be "subject to cross-examination concerning the statement";

b. Prior statement must be consistent with witness's testimony at trial;

c. Prior statement must have been a victim's "prompt complaint of sexually assaultive behavior.” See Nelson v. State, 137 Md. App. 402 (2001) (C. Moylan, J.) (13-year old girl's statement to her 11-year-old sister, made shortly after defendant left their apartment, that defendant had raped her, qualified for admission under Rule 5-802.1(d); victim’s statements a day later 
to her school counselor and to a nurse-sexual assault examiner would likely also have qualified but no objections to them were preserved).

d. These are admissible in both civil and criminal cases.

\section{Rule 802.1(e): Recorded Recollection...}

6. “Tender Years” Exception, Md. Crim. Pro. Code Ann. § 11-304, amended effective October 1, 2011

Changes made:

1. The statute applies to child victims under the age of 13 at the time of the OCS, rather than only under 12 .

2. It adds to the categories of potential witnesses who can testify to the child's statement:

a. a counselor licensed or certified in accordance with Md. Code Ann., Health Occ. tit. 17; and

b. a therapist licensed or certified in accordance with Md. Code Ann.

Health Occ. tit. 17.

3. In a criminal proceeding or in a juvenile proceeding other than a CINA proceeding, the child victim must testify at the proceeding.

4. The prosecution must give pretrial notice not only of the State's intention to introduce the child's out-of-court statement, but also must provide to the defense any audio or visual record of the statement or, if there is no such recording, the content of the statement.

5. In making its determination as to the admissibility of the child's statement, the court may find that a recording of the statement makes it unnecessary for the judge to examine the child victim.

\section{Rule 5-803: Hearsay Exceptions Applicable Regardless Whether the Declarant is Available or Unavailable to Testify at Trial, and Regardless Whether the Declarant Testifies or Not}

These OCS's may be proved by the declarant's own testimony to his or her OCS or by the testimony of any other witness having first-hand knowledge of the OCS. 
1. Rule 5-803(a), Statement by Party-Opponent: Opposing party’s own, adopted, authorized, agent's, or a co-conspirator's (often referred to as “admissions”) of a party-opponent.

a. Any such statement offered by one party, against the opposing party who made the adopted, etc. statement will not be excluded by the hearsay rule.

b. The phrase "admission against interest," found in some case law, is a misleading, mythological creature. Unlike under Rule 5-804(b)(3) (“declaration against interest” by a now unavailable declarant), under Rule 5803(a) there is no requirement that the OCS or "admission of a party opponent" have been disserving to the declarant at the time it was made.

\section{c. Rule 5-803(a)(1): Statement of party opponent by that party himself}

Flight Evidence: State v. Shim, 418 Md. 37, 56-59 (2011) (Adkins, J.) (error to have given "flight" instruction to jury when evidence showed only that defendant left scene of crime and took various steps to avoid being apprehended: these steps did not amount to "flight").

Song Lyrics: Hannah v. State, 420 Md. 339 (2011) (Murphy, J.) held that the trial court had committed reversible error in permitting the prosecutor to admit on cross-examination, after the alleged shooter-defendant had testified that he had no access to handguns and had never held one, the defendant's drawing of a gun and ten rap lyrics he had written about guns and shootings.

The appellate court distinguished inadmissible works of fiction from possibly admissible autobiographical statements of historical fact. It found that the evidence in this case lacked the special relevance needed to make it admissible under Rule 5-404(b), and amounted to mere propensity evidence as to violence. Finally, the door had not been opened by defendant's direct examination.

\section{d. Rule 5-803(a)(2): Adoptive Admissions}

(i) Defendant adopted alleged coconspirator's statements to a fellow inmate by standing by and adding details. Cox v. State, 194 Md. App. 629 (2010) (Graeff, J.) (affirming J. Watts), aff'd, 421 Md. 630 (2011) (Greene, J.) (Court of Appeals did not reach this issue: see n.4).

(ii) State's plea agreement with a witness that the witness would testify truthfully did not make that witness's actual testimony at trial of a likely codefendant admissible as an adoptive admission by the State in the subsequent trial of the defendant. Defense was permitted to call witness, but not to prove plea 
agreement. Armstead v. State, 195 Md. App. 599 (2010) (Kenney, J.), cert. denied, 418 Md. 191 (2011).

(iii)Tacit Admissions (by Silence: A person's silence in the face of another's statement can be interpreted as asquiescence in the truth of (adoption by silence of) the other's statement when three conditions are met:

(1)The party-opponent (or party's agent, etc.) heard the other's statement;

(2)The circumstances allowed for the party-opponent (or agent, etc.) to reply; and

(3)Under the circumstances, ordinarily a person similarly situated who was in disagreement would "speak up" and correct the speaker.

These preliminary facts regarding tacit admission (and other adoptive admissions also addressed by Rule 5-803(a)(2)) fall under Rule 5-104(b). If a reasonable jury could find them to be met, the judge should admit the evidence (subject to Rule 5-403).

2. Rule 5-803(b): Exceptions that Apply Whether or Not the Declarant Testifies at Trial

a. Rule 5-803(b)(1), Present sense impressions: a very small window of time.

Foundation elements:

(i) The OCS was made while the declarant was perceiving the event, or immediately afterwards; and

(ii) The OCS merely describes or explains the event.

b. Rule 5-803(b)(2), Excited utterances: a bigger window, as long as the declarant was still so upset by the event that s/he was not thinking before speaking, so as to be able to fabricate a self-serving statement.

Foundation elements:

(i) a startling event occurred;

(ii) OCS was made while the declarant remained under such stress that s/he could not stop to think (and thus to fabricate a self-serving statement) (look at all the relevant circumstances, including declarant's 
emotional state, time lapse, and whether leading questions were asked); and

(iii) The OCS relates to the starting event.

Witness, such as police officer, must lay foundation: describe affect of declarant; time lapse; questions asked, if any; other evidence of starting event, injuries, etc.

c. Rule 5-803(b)(3), Statements by declarant as to his or her present state of mind or physical condition: Declarant's assertions of his or her then-existing state of mind or physical condition (nonhearsay if not offered for TOMA, but admissible hearsay under Rule 5-803(b)(3) if offered for TOMA of the accused's asserted state of mind, rather than to prove a fact remembered or believed by the declarant). See Shepard $v$. United States, 290 U.S. 96 (1933).

\section{Rule 5-803(b)(3) Then Existing Mental, Emotional, or Physical Condition}

A statement of the declarant's then existing state of mind, emotion, sensation, or physical condition (such as intent, plan, motive, design, mental feeling, pain, and bodily health), offered to prove the declarant's then existing condition or the declarant's future action, but not including a statement of memory or belief to prove the fact remembered or believed unless it relates to the execution, revocation, identification, or terms of declarant's will.

Declarant's OCS as to his/her state of mind existing at time of OCS is:

(i) Admissible to show declarant's state of mind, when relevant.

See Edery v. Edery, 193 Md. App. 215 (2010) (Meredith, J.) (decedent's statements that she wanted to be buried in Israel were improperly excluded when offered to show her wishes).

Ex.Victim's statements of her fear of the defendant, made before her murder, and a domestic violence protective order that prohibited the defendant from entering the victim's home, admissible as relevant to defense raised that victim had invited defendant into her home, and 
gun went off accidentally. Case v. State, 188 Md. App. 279 (1997) (Murphy, J.).

(ii) Admissible to show declarant's subsequent action, after the statement, in accordance with stated intent. Mutual Life Ins. Co. v. Hillmon, 145 U.S. 285 (1892).

Ex. "I'm going to skip school tomorrow," admissible to show declarant played hooky the next day.

See Figgins v. Cochrane, 174 Md. App. 1, 27-31, (2007) (C. Moylan, J.) (Hillmon analysis inapplicable when no contention that declarant subsequently acted in accord with stated intent), aff'd, $430 \mathrm{Md}$. 392 (2008).

In Smith v. State, 423 Md. 573 (2011) (Rodowsky, J.) where the critical issue was whether the defendant had shot the victim or the victim had committed suicide, it was reversible error to admit State's evidence tending to show that the victim was not depressed, but to exclude testimony of a trooper --who had arrested the victim for DWI one month before the victim's death-- that the victim appeared to be depressed, stressed about the situation, and that the victim said to trooper, "This is the last thing I need in my life right now on top of all the...other shit going on in my life.”

The Court of Appeals did not analyze whether the OCS was offered for TOMA. The OCS could have been relevant just to show that was how the victim felt, not that a lot really was going on in the victim's life, in which case it would have been admissible as nonhearsay.

(iii) But inadmissible (under this hearsay exception) to show something that occurred prior to the statement, that caused declarant to have the particular state of mind. Shepard $v$. United States, 290 U.S. 96 (1933).

Ex. "I hate Phil because he hits me and breaks my toys." Admissible to show that declarant hates/dislikes Phil, if that is relevant to the case; inadmissible to show that Phil has hit the declarant. 
d.

Rule 5-803(b)(4), Statement of past or present facts, made while seeking medical treatment or diagnosis in contemplation of possible treatment.

\section{Rule 5-803(b)(4) Statements for Purposes of Medical Diagnosis or Treatment}

Statements made for purposes of medical treatment or medical diagnosis in contemplation of treatment and describing medical history, or past or present symptoms, pain, or sensation, or the inception or general character of the cause or external sources thereof insofar as reasonably pertinent to treatment or diagnosis in contemplation of treatment.

Required foundation:

(i) OCS made by person seeking medical treatment, should medical treatment become necessary; and

(ii) Declarant knew that OCS would be relied on for possible treatment. (This is the circumstantial guarantee of sincerity.)

If a patient is a child, it is particularly important that the doctor or nurse explains to the patient (or other declarant, e.g., parent) that what is said by the patient (or other declarant) will determine treatment. See State v. Coates, 405 Md. 131 (2008) (Greene, J.) (reversible error to admit evidence); Low v. State, 119 Md. 413 (1998) (Thieme and Byrnes, JJ.).

(iii) Only the facts related in the OCS that are reasonably pertinent to medical treatment or diagnosis in contemplation of treatment will be properly admissible.

Query:

Can the identification of the person who causes injuries ever be pertinent to medical treatment and thus admissible under 5-803(b)(4)?

Yes, e.g., to identify poison given;, and thus the proper antidote.

If child abuse, "not ordinarily." State v. Coates, 405 Md. 131 (2008) (Greene, J.), affg 175 Md. App. 588 (2002) (Hollander, J.) (it was known at time of OCS that child no longer had any contact with its perpetrator). But see In re Rachel T., $77 \mathrm{Md}$. 
App. 20, 33-36 (1988) (yes, due to possible testing for STD; possible removal from home).

A number of federal cases hold that relevance to psychological treatment, because of abuse, is sufficient.

\section{e. Rule 5-803(b)(6)-(23)...Another day!}

\section{f. Rule 5-803(b)(24), the “catch-all” exception}

Brock v. State, _ Md. App. _ 2012 WL 400439 (Feb. 9, 2012) (D. Eyler, J.) (trial court properly excluded unavailable declarant's OCS—recanting prior statements identifying defendant to police-- when offered by defense for TOMA; finding also that defense barely preserved the issue of whether the OCS was admissible to impeach the declarant under Rule 5-806, the court held that exclusion of the OCS was harmless error, in light of the other evidence in the case, where the OCS offered by State did not directly identify defendant).

\section{Hearsay Exceptions Applicable Only When the Declarant is Shown, under Rule 5-804(a), to be Unavailable to Testify}

1. $\quad$ Rule 5-804(b)(1), Prior testimony now offered against a party who had an opportunity and similar motive to examine the declarant at the earlier proceeding.

In Williams v. State, 416 Md. 670 (2010) (Raker, J.), the State had violated its discovery obligation under Rule 4-263(d), when it had not disclosed impeaching information known to a police officer that came to light after the first trial: that a key eye witness had said she was "legally blind." The eyewitness died before the retrial.

The second trial judge admitted the witness's videotaped testimony along with medical records about her vision and the detective's testimony that she had told him she was legally blind. The Court of Appeals' majority found these steps an inadequate substitute for the ability to cross-examine the eyewitness. It concluded that: "On remand, if the State wishes to introduce portions of the previously recorded testimony, the trial court should redact any portion which relates to what 
she might have seen or testimony depending upon her vision.” Judge Murphy, joined by Judge Rodowsky, dissented.

2. Rule 5-804(b)(2), Dying declarations.

See Head v. State, Chart 4.

\section{Rule 5-804(b)(3), Statements against interest.}

The Court of Appeals amended Rule 5-804(b)(3), effective January 1, 2011, so as to parallel the corollary amendment of Fed. R. Evid. 804(b)(3). The rule now makes it clear that whenever a statement against interest is offered "in a criminal case" under this hearsay exception, the requirement that "corroborating circumstances clearly indicate the trustworthiness of the statement” applies.

The earlier language restricting the application of this requirement to statements offered to “exculpate the accused," see Gray v. State, 368 Md. 529 (2002) (Cathell, J.), has been deleted.

4. Rule 5-804(b)(4), Statements of personal or family history, such as lineage.

5. The forfeiture by wrongdoing exceptions: Md. Rule 5-804(b)(5) (civil); Md. Cts. \& Jud. Proc. Code Ann. § 10-901 (certain criminal cases only).

Both rules restrict the types of statements potentially admissible to only recorded or written and signed statements (the same types that are also potentially substantively admissible prior inconsistent statements under Md. Rule 5-802.1(a), when the declarant testifies at trial). They also impose a notice requirement on the party seeking to offer evidence under the forfeiture exception.

The criminal statute foregoes the usual preliminary fact standards of Rule 5-104(a) and instead requires: (1) proof "by clear and convincing evidence that the party against whom the statement is offered engaged in, directed, or conspired to commit the wrongdoing that procured the unavailability of the declarant"; and (2) that the rules of evidence are "strictly applied" by the court in making this determination.

The criminal statute applies only in trials for certain crimes (generally, crimes of violence and drug crimes).

\section{E. Issues Related to Witness Intimidation}

1. Partial Closure of Courtroom Due to Suspected Witness Intimidation by Particular Spectators 
Longus v State, 416 Md. 433 (2010) (Greene, J.) (violation of defendant's Sixth Amendment right to public trial was reversible error; State's proffer of witness intimidation was inadequate to support exclusion from courtroom of two spectators, when there was neither specific showing that they had threatened the witness nor a voir dire of the witness, and the defense was not given an opportunity to respond to State's proffer) (note that, although J. Greene authored the plurality opinion, four judges and thus the court's majority - J. Harrell, concurring in part and dissenting in part, and J. Murphy, joined by J. Battaglia and J. Adkins, applied the "substantial reason" test for justification of partial closure rather than the “overriding interest’ test applied by J. Greene).

\section{Safety and Anonymity of Jurors}

By a Rules Order effective September 1, 2011, the Court of Appeals adopted new rules permitting a trial judge, who determines that juror safety or possible harassment or tampering is a concern, to protect the identity of jurors by having them referred to only by number rather than by name. Md. Rule 4-312(c) .

\section{F. Authentication of Internet and Cell Phone Evidence}

\section{Social Media}

Griffin v. State, 419 Md. 343 (2011) (Battaglia, J.) (finding inadequate authentication of MySpace profile and posting as coming from defendant's girlfriend despite circumstantial evidence). JJ. Harrell and Murphy dissented.

\section{E-Mails, I-M's, and Text Messages}

Dictum in Griffin v. State, 419 Md. 343, 361 n. 13 (2011) ("We further note that authentication concerns attendant to e-mails, instant messaging correspondence, and text messages differ significantly from those involving a MySpace profile and posting printout, because such correspondences [sic] is sent directly from one party to an intended recipient or recipients, rather than published for all to see.”). 


\section{Cell Phone Calls}

Carpenter v. State, 196 Md. App. 212, 225-30 (2010) (Thieme, J.) (both direct and circumstantial evidence properly authenticated sources of calls missed and received by cell phone; expert information technology evidence was not required).

\section{G. "By the Way"}

\section{Federal Rules Restyled}

The U.S. Supreme Court approved a "restyled" version of the Federal Rules of Evidence, which became effective December 1, 2011. The Committee notes accompanying each restyled rule emphasize that no substantive change in the rules is intended. The revisions are stylistic only and are meant to modernize and clarify the language of the rules. The revised rules and their complete legislative history may be found at www.uscourts.gov/RulesandPolicies/FederalRulemaking/Overview.aspx.

\section{More Information}

More information on Maryland and federal evidence law is included in McLain, volumes 5, 6, and 6A of MARYLAND EvidENCE: STATE AND FEDERAL, which is accessible on Westlaw as "[vol. no.] Maryland Evidence [sec. no.]" The section numbers generally correlate with the root of the Md. Rule number, e.g., Md. Rule 5-103 is discussed at §§ 103:1 et seq. and can be pulled up as "5 Maryland Evidence 103:1.” Volume 5 addresses the 100's-400’s Rules; volume 6 covers privileges through the 700's rules; Volume 6A covers 800's-1000's, plus the parol evidence rule at $\S 1101: 1$. 